\title{
Relation of Corporate Governance with Financial Performance
}

\author{
Naveed Ahmad ${ }^{1, *}$, Nadeem Iqbal ${ }^{2}$, Muhammad Sulaman Tariq ${ }^{3}$ \\ ${ }^{1}$ Faculty of Management Sciences, Indus International Institute, D. G. Khan, Pakistan \\ ${ }^{2}$ Faculty of Management Sciences, Ghazi University D. G. Khan, Pakistan \\ ${ }^{3}$ Finance Manager, Research and Development Solution, Islamabad, Pakistan \\ *E-mail address: naveeddgk2010@gmail.com
}

\begin{abstract}
The intention of the work is to prove that corporate governance is essential to uninterrupted operation of any corporation, while more consideration to the process such that governance. Hence it is transparent what is commonly intermediate by corporate governance. This work proves a link with the corporate governance and firm financial performance in insurance industry of Pakistan. It included three variables which are Audit committee independence, board independence and CEO duality for corporate governance. The degree of firm's performance is limited by return on equity and asset. This work gives a positive direction for exploring this concept.
\end{abstract}

Keywords: Corporate Governance; insurance; Pakistan; Financial Performance

\section{INTRODUCTION}

Corporate Governance has become pertaining to the current and local events due to its infinite addition in economic growth and for the progress of Nations. The opposed to presence of good Corporate Governance is main reason of failure in popularity of all good companies. In reality that insurance companies have understanding that it has great impact on economic growth of Pakistan. It is necessary to study such authoritative things. The insurance sector is significant part of the financial industry of the economy due to its financial inter-mediatory aspect. They offer safety to policy holder assuring the protection of their capital, In case of accident and invest their capital in business activities in the country. Such a result of the particular qualities of the insurance industry and the important addition, that is making to expand the economy to link between non presence of such study.

Overall, all the insurance companies are bounded to rules and regulations must protect their customers. The main sites of compulsion added rectification of board of directors according to the shareholders and best reveling added better internal and external audit for insurance companies. Every company included free-float market capitalization for index calculation. However, simultaneously interpret their affection and the index fluctuations.

In this paper we have never ended discussion to examine a link that retain among Corporate Governance and firm performance. From secondary data we examine collective findings, from those countries which are developed. 
Wolfeusohn who was the President of the WORLD BANK to explain the corporate governance as techniques and process to state corporate fairness, clarity and accountability. Commonly we can determine the corporate governance to begin the rules of process techniques and ways to prescribe and restrain the corporate affairs in such method to make secure the individual and combine interest of all the stake holders. Good corporate governance constantly increase the confidence of investors and lenders on company and have expressive authority on the strategic decision of the company. Consequently the variables of corporate governance (e.g. Board independence CEO duality and audit committee) works without limitations that influence on financial position of firms. Without regarding, to specific definition the expressive of corporate governance spread in a corporation due to disjunction of ownership and restrain. Besides agency theory describe that one who seeks favourable attitudes of individuals who posses powerful eagerness to in crease their own interest and is convenient to things. Consequently a contradictory occur between managers and owners. Logically that main reason of agency anticipation is what required to do to ignore opportunistic attitude since, the owner of firms recompense management to invest their capital in business. Knowledge a summitry happened due to managerial approach to all confidential knowledge then shareholders of company. It yields the companies get to utilize the wealth of firm for exterior benefits.

Consequently, agency theory proposed to corporate governance is a mechanism to eliminate these contradictions of interest by controlling management position and regulate is objectives which shareholders consequently Board of Directors is expressive factor for controlling the management and board members having freedom of some dimensions. Board independence assign comparatively relation of independent all directors in board. It found out positive link between board independence and firms position. The second expressive controlling instruments is to distinguish the role of CEO and chairman of board. No disjunction guide to CEO duality that is doubtful for organization because CEO has authority to control and evade the process. CEO duality occur the question who will control the management. Duality gives importance to CEO an board decision. Audit committee independence prefer to independent non executive directors, due to then occurrence of frauds in financial report will be less. It is also transfer for expressive governance. Klein find a negative link between earnings management and audit committee independence. Independent audit committees have low debt financing. Cost also find a positive and expressive link between ROE board composition and audit committee.

Pak Qatar Family Takaful is the pioneer of family takaful in Pakistan, being established in 2006 and commencing operation in 2007. PQFT Limited. Is chaired by share Ali Bin Abdullah al-thani, member of Qatar's Royal Family, sponsored by some of the strongest financial institution from the state of Qatar. The outgoing year was the first profitable year PQTF, made profit after tax of Rs.45.44 million, with PQFT limited posting a profit after tax of Rs.26.67 million and following course of Rs.18.77 million. Total contribution stood at Rs.3,873.4million, with PQFT at Rs.3,324.3 million \& PQGT at Rs.549.1 million.

The main purpose of this study is to explore the link between corporate governance and firms position. On the behalf of previous study, This study wants to examine influence on firms financial position that choose the corporate governance practices. Now we want to explore influence of corporate governance and firm financial position at Broadway. For this purpose particular variables of corporate governance (e.g. board independence CEO duality committee independence being pointed on by taking standards (e.g ROA, ROE). 


\section{LITERATURE REVIEW}

Corporate Governance having all the standards of enterprise to support the economic agents to participate in the productive procedures, to produce excess beyond what is needed within the organization and maintain a good contribution among the partners, capturing into attention what they bring for organization. There were many researches about the link between Corporate Governance and firm performance in insurance sector and some findings added in this review which are given below.

Shleifer et al. (1989) Find out that it is exciting, usually these managers to take themselves surrounding to the strong position, managers can disposes partners by surrounding themselves and restraining with job even if they have no more ability for survival of firm. The management disposes the funds and can easily work with labour than capturing cash outside like to shift from one person to another.

Davis et el. (1997) In their research find out five parts about the philosophy of management, a man employed to manage domestic concerns as trust, direct correspondence, to license, taking forever remaining steps and authoritatively increase achievement level. Daily et al. (2003) Assume as true that with in reach to inputs that will increase organizational achievement level, power of the action and keep continuity in performing functions for increasing firm performance.

Cheema et al. (2003) Investigated that firm progress history of Pakistan, to take measures about the right of possession, rank of financial institutions and also about the dynamics of the market and also participated to the scattered data in Pakistan by examining the different factors of corporate structure in the similar way that are important for corporate governance. Zingales (1998) In his study described corporate governance as extensively wide, multifaceted notion that is excessively applicable, however hard to do, because sort of its one aim to contain .

Lang et al. (1998) Investigated that shareholders, posses condensation in firms, having a vital role to restrain and guide the management to show interest in favour of the condensation group. While, corporate governance having authority to give permission to shareholders for the guidance of management for achieving more desirable position of their investment. Klein (2002) Stated that there is an opposite link among earnings management and audit committee independence.

Anderson et al. (2004) In their research described that independent audit committees in financial markets have lower debt financing costs. Fooladi (2011) Also examines that important performance of Corporate Governance is to minimise the contradictions of interest between owners and managers of firm. Corporate Governance attach the owners interest with managers to enhance the firm activity.

Khan et al. (2011) Stated in their study the influence of Corporate Governance on firm position. They selected insurance company of Pakistan for analysis purpose. They take authority condensation, CEO duality and board independence as a part and sequences of Corporate Governance measure the firm position by using ROA and ROE. They reached to the point that CEO duality have low achievement level and board independence increase the financial position of firms.

Mukhtar et al. (2009) Studied the link between Corporate Governance and firm position and for this reason they used Mann -Whitney U test to analyse position of companies that leads good governance with those companies which did not leads good corporate governance. Measures of any company used for the identification of good and bad corporate governance of companies. The measures of any firm performance are Financial ratios such as return on asset, return on equity, earning per share and profit margin Results of study showed that performance 
between companies which practise good corporate governance and companies that did not practise good corporate governance are similar.

Bhagat and Black (1999) investigated that there is opposite link among structure of the board, and firm financial position. This research also find out the result that in large public companies, there is no clear proof that board independence leads to firm profitability. Their study further investigated that there is no favour of the link among independent board and greater firm financial position. They said that board should be gathered with one of dependent $\&$ independent directors, so they may bring wide range of knowledge and skills which assures the best financial position of the firm.

Yasser et al. (2011) In their research investigated the link among four corporate governance processes (board size, board composition, CEO/chairman duality and audit committee independence) and firm financial position measures ( return on equity and profit margin ). The result have the positive interlink among the Corporate Governance procedures (board composition, board size and audit committee and performance measures, return on equity and profit margin). The impact of study is that, the size of the board should be small with in measurable limit and executive and non-executive directors must be present in the board. The research did not find out the affectionate link among the firm financial standards and CEO duality.

Kumar (2012) in his research examined the impact of outside directors on firm activity in 157 non-financial companies in India. It specially focused the importance of controlling by (non-executive non-independent) and independent directors on firm position. The conclusion is that presence of dependent and independent directors in board has determined effect on firm position while the presence of independent directors has no significant impact on firm value.

\section{METHODOLOGY}

The research engaged mixture of primary and secondary facts and figures to find out the results. These facts gathered by the use of financial statements of the companies for the period 2009-2012. In this study various factors have an impact on the linkage among corporate governance and firm's financial position. While in our research we just have following variables that are stated below.

\section{1. Independentble variable}

- CEO Duality: It prefers toward the two officers as one person was like CEO and other was Chairman.

- Board Independent: If board of the company depends one third or more upon the non executives' directors so we can say that board is independent, in case of less than one third, it is not independent.

- Audit Committee Independence: It included non-executives in the audit committee.

\section{2. Dependent variable}

- ROA: We calculate this by dividing, net income divided by total assets of the company.

- ROE: We calculate this by Net Income divided by shareholders equity of the company. 


\section{3. Sample and Data Collection}

For exploring the facts we have taken a listed company of insurance sector named as Pak - Qatar Family Takaful. Annual reports from 2009-2011 of this company studied for the collection of data.

Analysis of Insurance Company

$\begin{array}{lcccc}\text { Company } & \text { Year } & \text { CEO Duality } & \text { Board Independence } & \text { Audit Committee } \\ & & & & \\ \text { Pak Qatar } & 2009 & \text { No } & \text { Yes } & \text { Yes } \\ \text { Family Takaful } & 2010 & \text { No } & \text { Yes } & \text { Yes } \\ & 2011 & \text { No } & \text { Yes } & \text { Yes } \\ & 2012 & \text { No } & \text { Yes } & \text { Yes }\end{array}$

\section{Performance Measures}

$\begin{array}{ccc}\text { Year } & \text { ROA } & \text { ROE } \\ 2009 & (14.39 \%) & (15.45 \%) \\ 2010 & (18.02 \%) & (19.88 \%) \\ 2011 & (1.96 \%) & (2.16 \%) \\ 2012 & 5.22 \% & 6.00 \%\end{array}$

\section{DISCUSSION}

The analysis tells that financial performance of the Pak-Qatar Family Takaful is on rise due to good corporate governance as proved by No CEO Duality, but board independence and audit committee independence have positive impact.

After analysing the Pak-Qatar Family Takaful insurance company, we find out that there is no CEO Duality, Board is independent and audit committee is also independent but the performance of the company has decreased in the last years but now is positive. Performance was decreasing due to government regulations, high taxes and energy crisis. Performance increased when number of non-executive directors decreased (from 6 in 2009 to 4 in 2012).

On the base of above discussion, the study results that corporate governance is positively associated with the firm financial performance. So it is proved that there is a positive relationship between the corporate governance and firm's financial performance. After analysing the data we find that the ROA of Pak-Qatar Family Takaful has increased from (14.39 $\%$ ) in 2009 to $5.22 \%$ in 2012. Similarly the ROE was (15.45\%) in 2009 and increased to 6.00 $\%$ in 2012 . The equity has been improved.

\section{CONCLUSION - DIRECTIONS FOR FUTURE RESEARCH}

The study of Insurance has proved that there is positive relationship between the corporate governance and financial performance. However this study has focused on only three determinants of corporate governance (CEO Duality, board independent and audit committee independence). There exist other internal and external factors and determinants of corporate 
governance that need to be investigated. Further investigation also can be carried assuming other factors to examine the relationship between the corporate governance and firm financial performance. It can also be extended by considering other measures of performance.

\section{References}

[1] Abdullah S.N., Corporate Governance 4(4) (2004) 47-61.

[2] Baron A., Development and Learning in Organizations 17(3) (2003) 7-9.

[3] Bhagat S., Black B., Business Lawyer 54 (1999) 921-963.

[4] Brennan N., Accounting, Auditing \& Accountability Journal 14(4) (2001) 423-436.

[5] Brickley J.A., Coles J.L., Jarrel G., Journal of Corporate Finance 3 (1997) 189-220.

[6] Kalbers L.P., Forgarty T.J., Journal of Practice and theory 12(2) (1993) 24-49.

[7] Kang J., Shivdasani A., Journal of Financial Economics 38(1) (1995) 29-49.

[8] Klein A., J. Law Econ. 41 (1998) 275-303.

[9] Ozkan N., Journal of Multinational Financial Management 17(5) (2006) 349-364.

[10] Pallathitta R.G. (2005). Corporate governance and firm performance: An analysis of ownership structure, profit redistribution and diversification strategies of firms in India. Doctoral Thesis. University of Tilburg.

[12] Shleifer A., Vishny R.W., J. Finan. Econ. 20 (1997) 431-460.

[12] Weisbach M., J. Finan. Econ. 20 (1988) 431-460.

[13] Nadeem Iqbal, Naveed Ahmad, Hafeez Ullah, Aun Abbas, International Letters of Social and Humanistic Sciences 24 (2014) 15-25.

[14] Nadeem Iqbal, Najeeb Haider, Muhammad Ramzan Akhtar, Sumia Hafiz Abdul Karim, International Letters of Social and Humanistic Sciences 26 (2014) 71-81. 